\title{
WHITMAN'S ACHIEVEMENTS IN THE PERSONAL STYLE IN CALAMUS
}

\author{
M. WYNN THOMAS
}

THE INTENSELY PERSONAL NATURE of Whitman's Calamus poems has always been so evident as to attract comment whenever the sequence has been or is discussed. Witness the distinguished, but still fairly representative testimony of Gay Wilson Allen: "they vibrate," he writes of these poems, "with deep personal emotion, and some of them rank very high among the great love poems in world literature, though the love is not traditional heterosexual love." There was also a time when Calamus was supposed to be "personal" in a further, narrower sense: it was read as a richly autobiographical document, a faithful record of an experience actually undergone, an otherwise unknown love-affair in which Whitman was supposedly involved sometime during the late $1850 \mathrm{~s}$. But as this assumption proved, for various reasons, hard to justify and the interpretations based upon it difficult to sustain, it was replaced by a different view of the personal quality of the poetry. Its particular fascination for the sophisticated reader now lay in Whitman's unintentional self-disclosures, the exposure by the poetry of his private obsessions. This is a fascination which, proving predictably durable, has produced several outstanding studies of the collection, with the result that it has become customary to treat Calamus as lucratively "personal" poetry in this latest sense of the word.

In the process, however, there has been a marked tendency to underestimate the considerable degree of deliberate choice and conscious control with which, as there is ample evidence, Whitman labored to compose both individual poems and the collection as a whole. Since 1955 the evidence has existed for all to see in Fredson Bowers's invaluable, but relatively neglected edition of Whitman's manuscripts for the 1860 Leaves of Grass. Especially when combined with evidence from other sources, it reminds us that Whitman could be just as much of a poem-builder as his father (and indeed he himself) had been a house-builder: or, to draw an analogy from a different but equally relevant quarter, that he worked on his poems in much the same way that, as editor, he worked on his newspaper, pasting bits and pieces together to fashion a single satisfactory unit. ${ }^{2}$ It is clear that these particular working methods are far more evident, and were (for him) much more necessary when Whitman was engaged in amassing his longer poems than when he was engaged in writing his shorter lyrical pieces, but they remain reliable indicators of Whitman's instinctive attitude towards composition- 
that it was a branch of the construction industry, and that poems were as much made as born.

When Col. Robert Ingersoll asked Traubel "whether [Whitman's] writing was pretty well finished before [he] wrote at all or whether [he] wrote mainly, and revised, on paper," Traubel's reply met with Whitman's full subsequent approval: "I told him I thought you made lots of use of pens, inks and papers." 3 Although Whitman was usually very fond of emphasizing the spontaneous, inspired, organic qualities of his writing he could grow rather irritable when others took these descriptions too literally:

"Some of my enemies who think I write in the dark without premeditation ought to see that sheet of paper [i.e., the heavily revised manuscript of "The Sobbing of the Bells"]: there ain't a word there that seems to have had an easy time of it - that wasn't subjected to catawauling. I tell you, Horace, it's no fun for words when they get in my hands, though the howlers may not know it."4

In short, Whitman's attitude towards composition exhibits the very same dualism that Lawrence Buell has identified as characteristic of the "Transcendentalists' Literary Method": "a rhetoric of inspiration" was always provided with a ballast of common sense. Emerson himself, for instance, was "enamored of the idea of inspiration, and hastened to ascribe as much as possible to it," and yet "no method of composition could have been less spontaneous, indeed, than his practice of piecing together mosaics from journal to Lecture to essay." 5

Bowers's edition establishes that the idea of a cluster of poems entitled Calamus came to Whitman at a relatively late stage of his preparations for the third edition of Leaves of Grass. The first fragment of poem referring to the Calamus plant appears in manuscript in the spring of 1859 , but only sometime during the early summer of that year did Whitman appreciate the possibilities of the emblem and start organizing a sequence of poems around it. In constructing this sequence he drew together poems written, piecemeal, over a considerable period of time, and commenced adding to them others specifically written between 1859 and early 1860 with a Calamus grouping in mind. The poems in the Calamus section of the 1860 Leaves of Grass can therefore be divided into four groups. First, there are those written between 1856 and 1857 as part of the sequence of sixty-eight miscellaneous poems Whitman was then intending to add to the thirty-two poems of the second (1856) edition. Second, there is the group of twelve "Live Oak" poems which it is probable Whitman did not, at first, propose to publish. Third, there are the poems written immediately following Whitman's realization, during the early summer of 1859 , of the possibilities of the Calamus emblem that had emerged from a fragment written by him that spring. Fourth, there are the additional poems he produced a little later, sometime between the summer of 1859 and the publication of Leaves of Grass in 1860. 
It is clear, then, that the Calamus sequence as a whole achieved its published form only after Whitman had spent a great deal of time and energy deliberately fashioning poems of disparate origins into a single group. And the impulse to do this seems to have come not from any immediate crisis in Whitman's private life, but from a lucky chance in his artistic life-his discovery, during the course of a poem, of a whole territory of imagery which made aspects of his secret self authentically available to, but also in a sense exploitable by, his artistic self. And since the emphasis, in the study of Calamus, has traditionally fallen on the spontaneously self-expressive or the unconsciously self-revelatory aspects of the poetry, I shall, in the following discussion, be stressing, by way of compensation, Whitman's talent for "exploiting" his private feelings by treating them as the raw material of the poetic process. Because it is clear from the manuscripts that what matters to Whitman is not fidelity to the facts of personal experience, but the fullest possible development of the poetic and the human possibilities of this material.

Of Whitman's various manuscript revisions of poems and parts of poems, one change in particular has captured the general critical imagination. This is, of course, Whitman's alteration, sometime between the manuscript and the final printed stage, of his male comrade in "Once I passed through a populous celebrated city" to a female companion. Because the change is supposed to have been made for secretively personal rather than artistic reasons it has attracted considerable attention and prompted wide speculation. It is, for example, deemed sufficiently important to rate a special mention in the notes to the Penguin edition of the Complete Poems. Yet other equally interesting, not to say significant, changes in several of the Calamus poems remain virtually unnoticed, perhaps because far from reinforcing current prejudices about the sequence they threaten to call aspects of critical orthodoxy into question.

A notable case in point is the poem published as "We two boys together clinging / One the other never leaving," but which Whitman originally entitled "Razzia." In his highly stimulating discussion of Whitman's poetry, Edwin H. Miller comments as follows on the published version:

Fantasy is unchecked by social and rational controls, the poet recreates an adolescent's world in which two "armed and fearless" boys run roughshod over all external restraints, social, familial, religious, and political. . . . They play successfully (so they think) at all the male games ... but at the next moment they are frolicsome hermaphrodites. ... And so while they thumb their noses at society . . . their virility is but the wish of two very fearful lads who cling to each other. ${ }^{6}$

It is an excellent reading of the poem in its printed form, and Miller is fully justified, on the basis of Whitman's other writing, in supposing this to be a "fantasy" close to his heart. It would therefore seem to be but a short-and necessary-further step to regard the poem itself as private fantasy transferred 
with compulsive directness to the page. But here the manuscript version of the poem becomes distinctly interesting, because in it there is only a single (presumably adult) rover instead of the two boys. Consequently there is little suggestion of adolescent wish-fulfillment, no mention of Miller's "fearful lads who cling to each other," and in the absence of these elements the poem sounds remarkably like an additional section of "Song of Myself," containing further adventures of that familiar cosmic Self ("No law less than myself owning - . . / . . Fulfilling my foray," p. 108). ${ }^{7}$ And this is natural enough since, if Bowers's ingenious deductions are correct, this first version of the poem was written quite early - certainly before the summer of 1857 .

The pathos of loneliness and insecurity that Miller notices in "We two boys" is therefore to a very considerable extent due to the simple but radical changes Whitman made to the 1857 text when converting it into a Calamus poem. Moreover, when, by means of these changes, Whitman altered the emotional register of the poem, he also simultaneously provided the key word, "clinging," which, as Miller implicitly recognizes, gathered the new composition into clear focus. Such a lucid "centering" of the new poem seems to argue a sound grasp by Whitman as artist of the emotional range of "We two boys"-a range of emotions judged by him to be appropriate to the Calamus group. This successful conversion exercise accordingly suggests that the climate of feeling of the Calamus group is one that Whitman not only recognized but deliberately fostered, intensified and reveled in artistically-even when, as in the case of "These I, singing in spring," the poetry is almost certainly rooted in sensitive areas of personal experience.

"These I, singing in spring" is one of the poems composed by Whitman during the summer of 1857 specifically for the Calamus section he was then beginning to prepare, and in its extant manuscript form the poem differs very little from that which was finally printed. It is one of the best, and may well be the very best, of the Calamus sequence, by virtue of its poignant substitution of spectral lovers for the real comrades so achingly absent from Whitman's life. The bond between him and the thick crowd of friends by whom, in compensatory imagination, he is surrounded, is sealed by his ritual distribution of tokens in a ceremony involving an interestingly modified version of the language of flowers. And a "language" this indeed is in Whitman's case, in that it is an intimate mode of communication evolved where speech is of no further avail. The emphasis is upon the silence of the troop that gathers around him, and one peculiarity of silence is that it can be either the medium of extreme intimacy or of profound distance. In Whitman's poem it is both simultaneously, and thus precisely captures the ambivalent quality of fantasy -its ghostly amenability to desires that it nevertheless cannot substantially satisfy.

The poem mostly reproduces a mental state in which consciousness is consistently lagging behind, and following in the revelatory footsteps of action. Whitman finds himself doing things and going places "before I think 
where I get." By means of its distinctive grammatical and syntactical features-especially the use of the present participle-the poem creates a permanent state of being in media res: "Collecting, dispensing, singing in spring, there I wander with them." Words themselves arise out of and describe what is already happening, what already is being done, instead of being instrumental in the thought-control of actions. "Plucking something for tokenssomething for these, till I hit upon a name-tossing toward whoever is near me / Here! lilac, with a branch of pine. ..." Whitman doesn't really know what he means until he sees what he says in the light of what he finds himself doing. Instead of taking the word for the deed he lets the deed speak for itself and his actions speak to him far louder than words: "And here what I now draw from the water, wading in the pond-side $/ \ldots$ And this, $\mathrm{O}$ this shall henceforth be the token of comrades - this calamus-root shall. ..."

And it is here, at the very crux of the poem, that Whitman chose to alter the original version. Indeed so important is the change that he could in a sense be said to have drawn something rather different out of the water on this second, printed occasion. True, it is still a calamus-root, but its associations are radically different because Whitman has changed the significance for him of the location in which the calamus is found. Of the pond-side Whitman wrote in the first version:

(O there I saw him that tenderly loves me, and never separates from me

Therefore this shall be the special token of comradesthis calamus-root shall,

Interchange it, youths, with each other-Let none render it back,)... (p. 76).

But by 1860 the first line had been altered to read:

(O here I last saw him that tenderly loves me-and returns again, never to separate from me, ...) (p. 77).

It will be seen that in the former version Whitman is assured of the presence and affection of his lover, while in the latter he is separated from a lover of whose love, one might say, he accordingly tries to reassure himself. Obviously the change in the emotional situation of the singer profoundly affects the nature of the poem, his song. Of the second version of the decisive line it could be suggested that it arises from Whitman's own critical reading of the poem, during the course of which he intuited the nature and perhaps something of the source of its plangent pathos, and acknowledged it by rewriting the line so as to intimate loneliness and to accommodate uncertainty. In the manuscript he appears to offer the calamus root out of his superabundance of security, as a generous token of his confidence in love and as a blessing on 
lovers. But in the printed poem the root is given not as the token of an existing bond, but in an attempt at binding an absent lover to himself, which lends to his accompanying injunction more than a touch of desperation: "Interchange it, youths, with each other! Let none render it back!" (p. 77) To render it back would, like the returning of a ring, indicate the breaking of troth-and the fear betrayed by the urgency of Whitman's command is surely the fear that his own separation from his lover may occasion the severing of their bond of love.

The whole poem, in its 1860 form, can therefore be interpreted as a piece of white magic-the development of a fantasy ritual whose (unconscious) intention is to secure the perpetuation of love. As such it has affinities (as Whitman's poems so often do) with old ceremonies, customs and traditions-such as the marriage masque which concludes $A$ Midsummer Night's Dream. It should also be noted that the reader of the poem is him/ herself drawn into the ceremony, since the poem itself is the token which Whitman, "collecting and dispensing" words, offers to us, drawing us too into the magic circle of which he is the center. His fear, in this context, is a fear that we will "render it back," will reject his proffered gift-at least will refuse to take it on the compromising terms offered. This, as I shall argue more fully at the end of this essay, is a settled anxiety which repeatedly surfaces in the Calamus poems, and it is typical of Whitman in this mood that he should end not with an act of bounty but with a gesture of reserve, of secrecy, of withdrawal and of self-preservation:

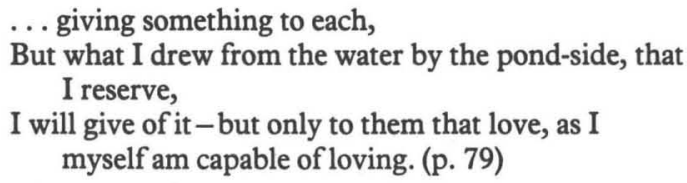

An altered sentence, then, can result in a distinctly different poem. It did in the case of "These I, singing in spring," and does again in the case of a second Calamus poem, "Long I thought that knowledge alone would suffice me," which first appeared in manuscript as number five of the "Live Oak with Moss" sequence. Simple in pattern, it involves the renunciation by Whitman of all the subjects which have previously engrossed his attention and commanded his energies as a poet, culminating in the renunciation of his poetry itself in favor of the company of his lover. When revising the piece for inclusion in the 1860 edition, Whitman retained it entire save for one pivotal line (or couple of lines in the manuscript version) upon which the whole poem turns from the repudiating of the old to the embracing of the new allegiance. Originally this read: "For I can be your singer of songs no longer-I have ceased to enjoy them. / I have found him who loves me, as I him, in perfect love" (p. 80). But subsequently it assumed a different 
form: "For I can be your singer of songs no longer-One who loves me is jealous of me, and withdraws me from all but love" (p. 81).

By inserting the word "jealous," Whitman injects a new tension into the whole piece, thus bringing it into line with the majority of Calamus poems, which explore the stresses and strains of the passional self, and encompass the despair as well as the comfort flowing from Whitman's urgent "need for comrades." But the important point is that it is Whitman the poet, the artist, who by introducing this note of jealousy deliberately builds additional emotional drama into his poem. In other words, far from being the record of a Whitman who is, to adapt Yeats's striking phrase, helpless before the contents of his own being, the Calamus poems, viewed in the light of manuscript evidence such as this, begin to seem like Whitman's construction, from his own experience, of a sort of model of the passional life as he knew it. They are more of a poet's self-possessed investigation of the parameters of passion, than the direct testimony of a man by passion possessed.

The implications of this point can best be worked out further with reference to the celebrated "confessional" qualities of the Calamus group. The two poems with which the sequence opens, "In paths untrodden" and "Scented herbage of my breast," are both outstanding examples of Whitman's preoccupation with confession, with making a clean breast of it. But they are also poems whose final, familiar forms are very significantly different from their beginnings in manuscript.

The crude patterning of the fragment from which "In paths untrodden" eventually evolved brings out sharply, by way of contrast, the subtlety of Whitman's revision and expansion. The initial six-line sketch involved a simple contrast between Whitman's past subjection and sacrifice of his own needs and nature to conventional standards, and his present escape to proclaim "the need of the love of comrades" (p. 68). What is completely missing, however, is any reference to a specific location -the "paths untrodden" and "the growth by margins of pond-waters" whose intimate sympathy with his own concealed nature it is that draws Whitman, in the printed text, into reciprocal speech: "Tallying and talked to here by tongues aromatic, / No longer abashed-for in this secluded spot I can respond as I would not dare elsewhere" (p. 67). True, Whitman speaks in the original of escaping to celebrate a "concealed [and] substantial life" (p. 68), but only in the "secluded spot" of the 1860 version does that "concealed" life acquire a substantial presence in the poem itself which is, thereby, transformed into an authentic confession. Moreover, by withholding the main verb at the outset, and by giving precedence to a series of subordinate phrases and clauses dominated by prepositions that mysteriously involve us with untrodden paths, ponds and escape, Whitman creates the atmospheric setting in which, quite literally entranced, he is uniquely able to come upon his heart's true geography: 
In paths untrodden,

In the growth by margins of pond-waters,

Escaped from the life that exhibits itself,

From all the standards hitherto published-from the pleasures, profits, conformities,

Which too long I was offering to feed my Soul ... (p. 67).

Contrast the hash Whitman subsequently managed to make of this opening in the Blue Book revision of the poem:

By the Calamus pond, I wander,

Through paths untrodden, and bowery, ... [etc. $]^{8}$

By offering us, from the very beginning, such a clear picture of himself, his surroundings and his actions, Whitman denudes his poem of all secrecythe protective, nourishing secrecy of the confessional. Whereas, by contrast, the whole of the $\mathbf{1 8 6 0}$ text is keyed from the beginning to Whitman's impression of being under the irresistible influence of a tutelary spirit of secret place, whose all-pervading presence is as insinuating and stimulating as the spicy calamus fragrance: "Strong upon me the life that does not conceal itself" (p. 69). Through this distant echo of a Quaker meeting and the movements of the Spirit ("Strong upon me ... ."), Whitman conveys an impression of being constrained to speak, and further convinces us that the poem itself consists of this compulsive speaking.

And yet one recalls that the words "spoken" at this point in the printed poem come from Whitman's previous manuscript fragment, and so antedate the Calamus tongues which, in the 1860 edition, they are so hauntingly made to "tally." Sometime between 1859 and 1860 Whitman deliberately and successfully built his fragment up into a confession, as he built emotional drama into "These I, singing in spring"-and indeed viewed from this perspective the confessional impulse is the dramatic ingredient that was added to "In paths untrodden."

At around the same time Whitman pieced together the great Calamus poem "Scented herbage of my breast." Bowers's analysis of the manuscript shows that he already had a long passage, roughly corresponding to lines 6 to the end of the printed poem, from which he commenced working. To this he added ten introductory lines, the first five of which he subsequently discarded, so as to begin not with confident declamation ("Was it I who walked the earth disclaiming all except what I had in myself?" [p. 68]) but with the intensely brooding invocatory address to the "Scented herbage of my breast." Yet in so doing he was simply keeping faith with a poem that was already substantially complete. The change effected through revision in this case did not, then, result in a confessional poem, as it did in the previous example, since "Scented herbage" was already, in its earliest extant 
form, a poem of private disclosure: "O slender leaves! O blossoms of my blood! I permit you to tell, in your own way, of the heart that is under you, where your roots are!" (p. 70)

Instead, the really significant change was made elsewhere and otherwise, and again shows Whitman deliberately intensifying the emotional and psychological drama of the work. It comes in the revised version of the poem when an impatient and suddenly determined Whitman announces a break with the leaves and blossoms whose timidity is now seen to disqualify them from giving tongue to his new-found frankness. Having wooed them assiduously throughout the gestation period of his confidence, Whitman now discovers that, before he can "unbare this broad breast of mine," he has to move beyond the equivocal shelter of his collusion with these beloved flowers of language, these suggestive figures of speech, and expose himself in a naked plainness of statement:

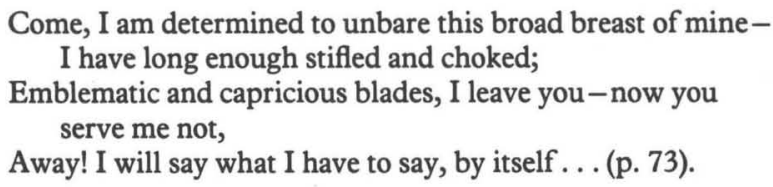

By adding these lines Whitman turned his subsequent declarations of commitment to Love and Death from being a natural development of the existing mode of feeling and speaking of the poem (which they were in the first version) into a revolutionary new departure. In so doing he evidently wanted to dramatize the need for openness, and to deprecate the subterfuges and equivocations of secrecy.

But there is room to argue that what he actually achieved was something so different as to be virtually the opposite of his intentions. Because the difference between the glib generalizations which this spirit of openness actually produces ("I will sound myself and comrades only-I will never again utter a call, only their call" [p. 73], etc.) and the painful probings after meaning that characterized his investigation of the scented herbage ("O I do not know what you mean, there underneath yourselves" [p. 71]) raises an unavoidable question: is what has now emerged so triumphantly into the light of open statement really the same as that which Whitman previously sensed to be hidden in the dark at the root? Although this is a question that could obviously lead into a consideration of the evasions and obstructions produced by Whitman's own inner conflicts, as those are reflected in his poetry, I prefer in this essay to treat it as a question that reveals the kind of problem that is intrinsic to confession as such and which enables us to recognize the sort of Gordian knot that is so frequently tied in the very act of confession.

One of the real strengths of the Calamus poems, regarded as an example of confessional writing, is that they meet the requirements of that demanding 
form, as those were astutely defined by Brian Way during his recent discussion of Scott Fitzgerald's own confessional work, The Crack-Up:

Confessional writing . . . is a slippery form. ... [N]o literary convention uses the rhetoric of sincerity more insistently, and yet there is no mode of expression in which it is more difficult to be really sincere. . . . The act of public confession makes it almost impossible for a writer to be honest with himself: it also places him in a false position with regard to his audience. . . . Confessional writing cannot be artistically worthwhile unless the author finds some way of showing the reader that he is conscious of the treacherous ground that lies between them. 9

Way goes on specifically to mention the American confessional poets of the 1960s: "Often they fail for the same reason that the crack-up essays fail-because they simply talk about themselves without showing any awareness of what this involves. Their successes are due not so much to the intrinsic interest of what they confess, as to the insight they occasionally reveal into the dubious role of confession itself."10 He particularly admires Sylvia Plath's success, in "Lady Lazarus," in "dramatising the difficulties of the confessional poet," which is also one of Whitman's signal achievements in Calamus.

Indeed the "difficulties of the confessional poet" are very evident in Whitman's intriguing attempts to navigate the turbulent cross-currents of the confessional journey. Confessional words, for instance, threaten to prove inadequate to the emotional demands, the demands for perfect self-expression, made upon them (e.g., "Not heaving from my ribb'd breast only"); but they also threaten to "expose me more than all my other poems" ("Here my last words," p. 113). "Language," Iris Murdoch has written following Sartre, "is that aspect of me which, in laying me open to interpretation, gives me away." 11 In Calamus Whitman repeatedly veers between the desire to give himself away through the directest possible use of language, and an anxiety that his words may give more of himself away than he is either able to anticipate or control-and there is of course always the further possibility that others may not ultimately take his words in the spirit in which they are given, and may in consequence mis-take and misrepresent him.

It is therefore not surprising to find that if Whitman boasts, with apparent confidence, of the simple power of his poem to elicit an intuitive, sympathetic response from the reader, he also at times resorts, with something approaching desperation, to a riddling, testing speech that, intelligible only to the initiated, will protect the holy treasures of the Self's inner sanctum from being looted by the merely curious. In so many of the Calamus poems (including "These I, singing in spring" and "Roots and leaves themselves alone are these") Whitman is to be discovered renewing his search for what Edward Thomas poignantly called "a language not to be betrayed"-a faithfully confessional language that will not itself betray, and that is proof both against betrayal from within (by the subterfuges of the speaker) and 
from without (by the listener). ${ }^{12}$ Perhaps the strangest and most complex of the poems dealing with this theme is "Whoever You Are Holding Me Now in Hand," where a brief erotic dream of blissful mutuality (silence is again, significantly, the medium of this consummation) surfaces only to be islanded in the middle of Whitman's deep doubts concerning the possibility of perfect disclosure of one self to another, and of complete discovery (and acceptance) by one self of another. ${ }^{13}$

Through this essay I have been arguing, in effect, for the need to note in the Whitman of Calamus the presence of what Graham Greene famously called the chip of ice that is in every true artist's heart. The impression of intensely personal drama in several of these poems as we know them is something that, as has been seen, Whitman worked, with a considerable degree of artistic detachment, to produce and to enhance. And it is again this very same detachment, operating perhaps at a more instinctive level, that enabled Whitman to produce a poetry that is most profoundly and convincingly confessional by virtue of its implicit admissions and explicit investigations of "the difficulties of the confessional poet."

\section{The University of Wales, Swansea}

\section{NOTES}

1 Gay Wilson Allen, A Reader's Guide to Walt Whitman (New York: Octagon Books, 1979), p. 71 .

2 C. J. Furness, ed., Walt Whitman's Workshop (New York: Russell \& Russell, 1964 reprint), p. 188 and pp. 199-200. Contrast the Introduction, in which he emphasizes inspiration.

3 Horace Traubel, With Walt Whitman in Camden (New York: Rowman \& Littlefield Inc., 1961 reprint), 2:48.

4 Traubel, 2:136.

5 Lawrence Buell, Literary Transcendentalism: Style and Vision in the American Renaissance (Ithaca \& London: Cornell University Press, 1973), p. 57.

6 Edwin H. Miller, Walt Whitman's Poetry: A Psychological fourney (New York: New York University Press, 1968), p. 165.

7 All page references are to Fredson Bowers, Whitman's Manuscripts, Leaves of Grass (1860) (Chicago: University of Chicago Press, 1955).

8 Arthur Golden, ed., Walt Whitman's Blue Book (New York: New York Public Library, 1968), 1:341.

9 Brian Way, F. Scott Fitzgerald and the Art of Social Fiction (London: Edward Arnold, 1980), p. 151.

10 Way, p. 152.

11 Quoted in Geoffrey Hartman, Saving the Text (Baltimore and London: Johns Hopkins University Press, 1981), p. 137. 
12 Cf. Roy Harvey Pearce's comment that "the Enfans d'Adam sequence tells us how it iswhat it means, what it costs-to be a maker of poems and the Calamus sequence how it is to be a reader of poems - in the first instance the analogue is procreation; in the second it is community." ("Whitman Justified," in R. W. B. Lewis, ed., The Presence of Walt Whitman [New York: Columbia University Press, 1962], p. 94).

13 I explore the confessional elements in Calamus rather differently in a forthcoming essay in the American Transcendental Quarterly. 